\title{
Root parasitic nematodes in nursery plants imported to Finland in 1980
}

\author{
SIRPA KURPPA \\ Agricultural Research Centre, Department of Pest Investigation, \\ 31600 Jokioinen, Finland
}

\begin{abstract}
Injurious nematodes were found in 201 of the investigated 670 plant stocks of 42 imported consignments. Infections by quarantine nematodes appeared in 100 stocks of 26 consignments, 15 thereof including 3 or more infected plant stocks each.

Root knot nematode, Meloidogyne spp., appeared in 81 stocks, i.e. $12 \%$ of the investigated material. The infections were found in 40 plant species, relatively often in barberry, Berberis sp., and in peony, Paeonia sp.. Among garden roses, 26 out of 167 stocks investigated were infected by root knot nematodes.

Root lesion nematode, Pratylenchus penetrans (Cobb) Chitwood \& Oteifa, of $P$. convallariae Seinhorst was found in 28 plant stocks, i.e. $4 \%$ of the investigated material. Several Pratylenchus-infected stocks were found among roses, raspberry and barberry.

Potato rot nematode, Ditylenchus destructor Thorne, was found in one rose stock and related D. myceliophagus J. B. Goodey in 12 stocks of various plants. Several ectoparasitic species were found in very low numbers. Virus vectors, Trichodorus primitivus (de Man) Micoletzky and $T$. viruliferus Hooper, were detected in a total of four stocks, but too few for virus transmission tests.

The transmissability of the detected nematodes was discussed, and the risks of introduction of nematode pests to the country was re-assessed.
\end{abstract}

\section{Introduction}

Dispersal of nematode pests in the international market of plant material has repeatedly been reported (BINGEFORS 1967, BRAACH 1978, ESSER 1978). In the 1950's the introduction of the stem nematode, Ditylenchus dipsaci (Kuhn) Filipjev, and the sugarbeet nematode Heterodera schachtii Schmidt was associated with the import of their host plants to Finland (RoIvainen 1961, RoIvainen et al.
1962). Later, a few cases of introduced root knot nematodes, Meloidogyne sp., have appeared in greenhouse cultivations. In 1976 - 80, the import of nursery plants, especially roses, was prohibited on the basis of local phytosanitary regulations because of root knot nematodes (ANON. 1976-80).

In the Finnish quarantine regulations, $\mathrm{Di}$ tylenchus destructor Thorne, Globodera pallida Stone, G. rostochiensis Wollenweber, 
Radopholus similis (Cobb) Thorne, Xiphinema americanum Cobb, D. dipsaci and Meloidogyne spp. are included in the A2 list and Bursaphelenchus xylophilus (Steiner \& Buhrer) Nickle together with Nacobbus aberrans (Thorne) Thorne \& Allen in the A1 list. Imported material is supposed to be substantially free from these nematodes. The nematodes of which slight infections are accepted (B list) include Aphelenchoides spp., Pratylenchus convallariae Seinhorst, $P$, penetrans (Cobb) Chitwood \& Oteifa and P. vulnus Allen \& Jensen.

In 1975-80, plant propagation material for Finnish horticultural nurseries was imported mainly from Central Europe, particularly from the Netherlands, and occasionally from non-European countries (ANON. 1976-80). In the few surveys published on the growing areas of European nurseries, certain root parasitic nematodes, including Meloidogyne and Pratylenchus species occured commonly (Nolte and Dieter 1957, Sonderhousen et al. 1968, KozLOWSKA and WASILEWSKA 1972, SAly 1979, Cotten and Roberts 1981).

The objective of this survey on plant material imported to Finland in 1980 is to reveal the potential sources of nematode infections risky for nursery cultivation in the field as well as in greenhouses.

\section{Materials and methods}

\section{Samples}

Root samples were taken in April 1980 arbitrarily from the imported plant material by the quarantine officers performing routine plant inspection. The number of samples taken was 670 , and each sample represented a uniform stock of imported plants. Samples were taken from 42 consignments, each sent by one exporter and including a minimum of 10 plant stocks. The consignments came from European countries: 17 from the Netherlands, 15 from Denmark, 7 from West Germany, 1 from Belgium, Sweden and United Kingdom, each. (The total distribution of consignments from these countries in $1976-80$ was $65 \%$, $18 \%, 6 \%, 4 \%, 5 \%$ and $2 \%$, respectively.) The size of the samples varied between $20-200 \mathrm{~g}$, depending on the structure of the root system, big samples taken from roots with large diameter. The samples were transported in closed plastic bags.

\section{Extraction and identification}

In the laboratory of the Department of Agricultural and Forest Zoology, University of Helsinki, the uncleaned roots were cut or chopped into pieces of less than $0.5 \mathrm{~cm}$ in size and a subsample of $10 \mathrm{~g}$ was processed by the centrifugal flotation method (CAVEvEss and JENSEN 1955) and another subsample of $10 \mathrm{~g}$ on a mistifier apparatus (HoOPER 1970a) for five days to extract the nematodes. The nematodes were thereafter fixed in a mixture of formalin, triethanolamine and water (T.A.F.) (HOOPER 1970b). The total number of nematodes and the number of nematodes of the genera Ditylenchus spp., Meloidogyne spp., the spiral nematodes (Helicotylenchus spp., Rotylenchus spp.), Tylenchorhynchus spp., the trichodorid nematodes and the longidorid nematodes were counted. The identifications were done from subsamples mounted in glycerol by the Seinhorst slow method (HoOPER 1970b). Special attention was paid to species mentioned in the plant quarantine regulations issued in Finland. A sample was defined as infected if any of the above nematodes could be detected by either of the two extraction methods.

\section{Results}

Frequency of infections

Nematodes belonging to the genera Ditylenchus, Meloidogyne, Pratylenchus, Helicotylenchus, Rotylenchus, Tylenchorhynchus and Trichodorus were found in 201 of the 670 investigated root stocks. The number of infections specified in the quarantine regulations 
was 115 in 100 stocks. The occurrence of infections in the most commonly imported plants is presented in Table 1. The infected plant stocks were distributed by consignments as follows: all plant stocks in a consignment free from any quarantine infections 16 , one stock infected 4, two stocks infected 7 , and 3 or more stocks infected 15 consignments (mean 3.8). (The consignments consisted a minimum of 10 plant stocks.)

\section{Potato rot nematode}

The plant parasitic Ditylenchus species was rarely encountered (Table 1 ). The only $D$. destructor infection was found in rose stock (cv. Europaena) also infected by Meloidogyne spp.. No visible symptoms were seen in the infected roots. The other Ditylenchus species was D. myceliophagus J. B. Goodey which was found in 12 root stocks of the following plants:

Ajuga reptans L. Potentilla fruticosa L. Aronia prunifolia Prunus domestica (Marsh.) Rehd. L.

Clematis $\times$ jack- $\quad$ Prunus padus $\mathrm{L}$. manii T. Moore Rosa L. sp.

Table 1. Occurrence of infections of phytosanitarily important nematodes in the common plant genera importèd to Finland in 1980 .

\begin{tabular}{|c|c|c|c|c|c|}
\hline \multirow[t]{2}{*}{ Plant } & \multirow{2}{*}{$\begin{array}{c}\text { No } \\
\text { of } \\
\text { stocks }\end{array}$} & \multicolumn{4}{|c|}{ Number of stocks infected by } \\
\hline & & D. des. & Mel.spp. & P. con. & P. pen. \# \\
\hline Acer L. sp. & 20 & & 1 & 1 & \\
\hline Amelanchier Medic. sp. & 10 & & & & \\
\hline Astible D.Don sp. & 12 & & & & \\
\hline Berberis L. sp. & 18 & & 7 & & 3 \\
\hline Caragana Fabr. sp. & 10 & & & & \\
\hline Cornus L. sp. & 10 & & 1 & & \\
\hline \multicolumn{6}{|l|}{ Hemerocallis L. sp. + } \\
\hline Convallariae L. sp. & 10 & & 3 & 1 & \\
\hline Hydrangea L. sp. & 11 & & 2 & & \\
\hline Lonicera L. sp. & 10 & & 1 & & \\
\hline Malus Mill sp. & 12 & & 2 & & \\
\hline Paeonia L. sp. & 10 & & 4 & & 1 \\
\hline Philadelphus L. sp. & 10 & & 2 & & \\
\hline Phlox L. sp. & 10 & & 1 & & \\
\hline \multicolumn{6}{|l|}{ Picea A.Dietr. sp. + } \\
\hline Pinus L. sp. & 13 & & 4 & & \\
\hline Potentilla L. sp. & 14 & & 3 & & 2 \\
\hline Prunus L. sp. & 21 & & 1 & & \\
\hline Rhododendron L. sp. & 10 & & 2 & & \\
\hline Ribes L. + Rubus L. sp. & 37 & & 5 & 2 & 3 \\
\hline Rosa L. sp. & 167 & 1 & 26 & 5 & 5 \\
\hline Salix L. sp. & 10 & & & & \\
\hline Spiraea L. sp. & 15 & & 3 & & 1 \\
\hline Syringa L. sp. & 20 & & 4 & & 2 \\
\hline Taxus L. + Thuja L. sp. & 10 & & 3 & & \\
\hline Tilia L. sp. & 12 & & 2 & & \\
\hline Rosa L. sp. \# \# & 40 & & 4 & 1 & 1 \\
\hline Total & 512 & 1 & 81 & 10 & 18 \\
\hline
\end{tabular}

$\#$ D. des. = Ditylenchus destructor

Mel. spp. = Meloidogyne spp.

$\mathrm{P}$. con. = Pratylenchus convallariae

$\mathrm{P}$. pen. $\quad=P$. penetrans

\# \# roses for cut flower production (30) and for house plants (10) 


\section{Root knot nematodes}

Meloidogyne infections occurred most frequently in the imported plant material (Table 1.). According to the juvenile morphology, the Meloidogyne specięs included $M$. arenaria (Neal) Chitwood, M. graminicola Golden \& Birchfield, $M$. hapla Chitwood, $M$. incognita (Kofold \& White) Chitwood, M. javanica (Treub) Chitwood and $M$. naasi Franklin. The relative frequency within species was not estimated. Juvenile root knot nematodes were found among the following plants:

Acer platanoides $\mathrm{L}$. Aesculus hippocastanum L. Aronia prunifolia Berberis thunbergii DC.

Convallaria majalis $\mathrm{L}$. Cornus alba $\mathrm{L}$.

Hemerocallis L. sp. Humulus lupulus L. Hydrangea paniculata Sieb.

Juniperus communis L.

Lonicera tatarica L.

Lychnis chalcedonica L.

Malus baccata (L.) Moench

M. $\times$ domestica Borkh. Paeonia officinalis L.

Parthenocissus guinguefolia (L.) Planch. Philadelphus coronarius $\mathrm{L}$.

$P . \times$ virginalis $\mathrm{L}$.

Phlox paniculata $\mathrm{L}$. Physocarpus (Cambess.) Maxim. sp. Picea omorica (Panc.) Purk.
The highest number of juveniles appeared in a stock of Phlox paniculata (150 juveniles $/ 10 \mathrm{~g}$ roots). There were no symptoms in these roots. Among roses, the highest number of infections and also the highest number of nematodes per sample were found in garden roses but also 3 out of 10 stocks of multifloral roses for house plants were infected.

\section{Root lesion nematodes}

Of the two phytosanitarily important Pratylenchus species, $P$. penetrans occured more commonly (Table 1), and the infections of $P$. penetrans were slightly stronger than those of $P$. convallariae. All the infections were weak, the maximum number of adults and juveniles in the roots being $50 P$. penetrans and $35 P$. convallariae / g roots. No visible symtoms of infections were seen. The other Pratylenchus species, $P$. crenatus Loof, $P$. fallax Seinhorst and $P$. pratensis (de Man) Filipjev were found in 18 plant stocks. The plant species of where Pratylenchus infections were found are as follows:

\section{P. penetrans: $\quad$ P. convallariae:}

Berberis thunbergii Acer ginnala Maxim.

Paeonia officinalis Ribes alpinum

Potentilla fruticosa Rosa sp.

Ribes pallidum Rubus idaeus

Rosa sp.

Rubus idaeus $\quad$ P. crenatus:

Spiraea $\times$ cineraria Ajuga reptans
Syringa reflexa

Schneid.

S. vulgaris $\mathrm{L}$.

Viburnum opulus L. Rosa sp.

L.

Tilia cordata Mill.

Vaccinium corym-

bosum L.

Viburnum opulus

P. fallax:

Hydrangea anomala $P$. pratensis:

D. Don

Thuja occidentalis

castanum L.

Ribes L. sp.
Zabel

Aesculus hippo-

Lonicera tatarica

Paeonia L. sp.

About $40 \%$ of the Pratylenchus infections occurred in the roots infected also by Meloi- 
dogyne spp., but there were no mixed infections between the different Pratylenchus species. Among roses, infected stocks were found in all types of cultivars: those used for outdoor cultivation as well as those for cut flower production or for house plants.

\section{Ectoparasitic root nematodes}

Pin nematodes were found in 8 stocks: Paratylenchus bukowinensis Micoletzky in Hydrangea petiolaris and P. projectus Jenkins in Cornus alba. The stylet nematodes Tylenchorhynchus claytoni Steiner and $T$. dubius (Butschli) Filipjev were found in 11 stocks, including the following plant species:

T. claytoni:

Ajuga reptans

Convallaria majalis

Cornus L. sp.

Rhododendron sp.

Ribes nigrum

Rosa sp.

Syringa sp.

Spiral nematodes were detected in 8 stocks, including several mixed infections of two species. Helicotylenchus pseudorobustus (Steiner) Golden and $H$. varicaudatus Yuen occured as follows:

\section{H. pseudorobustus: \\ H. varicaudatus: \\ Hydrangea anomala \\ Rhododendron sp.}

The genus Rotylenchus occured as $R$. fallorobustus (Goodey) Sher and $R$. robustus (de Man) Filipjev:

$\begin{array}{ll}\text { R. fallorobustus: } & R \text {. robustus: } \\ \text { Acer ginnala } & \text { Astible } \mathrm{sp} . \\ \text { Aesculus hippo- } & \text { Rhododendron } \\ \text { castanum } & \text { japonicum } \\ \begin{array}{l}\text { Astible } \text { sp. } \\ \text { Rhododendron japo- }\end{array} & \begin{array}{l}\text { Vaccinium corym- } \\ \text { nicum } \text { (A. Gray) }\end{array} \\ \begin{array}{l}\text { Suring. } \\ \text { Syringa reflexa }\end{array} & \begin{array}{l}\text { R. goodeyi: } \\ \text { Aesculus hippo- } \\ \end{array} \\ & \text { castanum }\end{array}$

The stubby root nematodes Trichodorus spp. were found in four stocks: $T$. primitivus (de Man) Micotetzky in Potentilla fruticosa and in two stocks of in Rosa rugosa Thumb. and $T$. viruliferus Hooper in Hydrangea anomala. There were too few nematodes for virus transmission test.

\section{Discussion}

The high frequency of Meloidogyne infections was expected on the basis of the superior international dissemination of these nematodes (SASSER 1977). Larvae of Meloidogyne spp. where, however, rare in the Danish nurseries and rose fields (SONDERHOUSEN et al. 1968) and equally infrequent further south (Wolny 1980, KozlowsKa and WasilewSKA 1972). The fairly high frequency of Meloidogyne spp. larvae in roots of this survey may have several explanations. Either the imported plant material originated from particularly highly infected areas or even from third countries, or the material was infected during preparation for exports or during transportation.

The inadequate capacity of transferred root knot nematodes to adapt to new situations (SASSER 1977) must be the reason why Meloidogyne infections have not been more frequent in local nurseries. In greenhouses, many species of the root knot nematodes can be expected quickly to build up injurious populations. It is therefore of major importance that attention be paid to the quality of the material. In open fields the maximum accumulated temperature in southern Finland is in most years double the temperature needed for larval development of $M$. hapla (VRAIN et al. 1978). Survival of infective populations of $M$. hapla in comparable conditions has been shown (JoHnson and PotTer 1980). The great strain specific differences in temperature thresholds for survival demonstrated with $M$. javanica by Daulton and NusBaum (1961) and the ability of SAYRE'S $M$. hapla population to tolerate freezing temperatures (SAYRE 1964) are of special concern. 
The Pratylenchus species described above have, previously, been found in Finland ( $\mathrm{S}_{\mathrm{A}}$ RAKOSKI 1978). P. penetrans has caused injuries in greenhouse carnations, young apple trees, Crataegus sp. and onions (AnON. 1963 -64 , SARAKOSKI 1978). The low frequency of Pratylenchus spp. in the detected roots, in contrast to the high frequency of these nematodes in the European nurseries (SoNDERHOUSEN et al. 1968), might be due to the nematodes' mobility during harvesting or storage of the plants for import. P. penetrans has shown properties which make it transportable (WYSS 1970), and WoLNY (1980) found quite a number of root lesion nematodes in the roots of nursery plants grown in infested soil. After all, even a weakly disseminated population might become important because of the relatively high infectivity of Pratylenchus species at low temperatures (FerRIS 1970, KIMPINSKI and WILLIS 1981) and because of their interactions with pathogenic fungi.

The ectoparasitic nematode species found here were mostly the same as found by Wolny (1980). Many of them are capable of adaptation, enabling survival during transportation in roots which should be free from any loose soil. D. myceliophagus forms 'curds', aggregates of a cryptobiotic stage (CAIRNS 1953, Perry 1977). D. destructor which is devoid of any inactive stage can, on the other hand, survive on fungal hyphae. The Paratylenchus species and $T$. claytoni are at a certain stage able to stay inactive and desiccated even for years (MCGLOHON et al. 1962, BRZESKI 1976). T. dubius has been mentioned cabable of being spread by wind (Simons 1973), and some unidentified Helicotylenchus nematodes were found cabable of the same (ORR and NEWTON 1971). R. robustus survives long pe-

\section{References}

ANDERSSON, S. 1967. Investigations on the occurrence and behaviour of Ditylenchus destructor in Sweden. Nematologica 13: 406-416.

AnON. 1963-64. Maatalouden tutkimuskeskus. Tuho- riods without a host plant (SEINHORST and KENIASU 1969) and has been found fairly drought tolerant (Wyss 1970). The nematodes most sensitive to desiccation and to all disturbances are the trichodorides (WYSS 1970). $T$. viruliferus is, however, known to shield itself by burrowing into cracks it has produced in the roots (PITCHer and Mcnamara 1970). No such behaviour has been reported about T. primitivus.

The introduction of the above mentioned and other new ectoparasitic species is highly probable, but establishment of injurious populations of the species is unlikely if the infections remain as weak as here described. However, severe infestations of the potato rot nematode, $D$. destructor, has been reported in southern Sweden (ANDERSSON 1967), and the nematode has a great number of hosts among Finnish plants and many universally common fungal hosts (FAULKNER and DARLING 1961). The populations of $T$. dubius are known to increase at $10^{\circ} \mathrm{C}$ (MALEK 1980). $R$. robustus was injurious in the Scottish forest nureseries and it has been shown to start feeding at a temperature as low as $0.5^{\circ} \mathrm{C}$ (BOAG 1980), but its development is very slow (BOAG 1982).

As for the Trichodorus species, the viruses potentially transmitted by them would indirectly make the nematodes economically very important. Neither of the two Trichodorus species are known in Finland, but $T$. primitivus is well distributed in Sweden (PERSSON 1968). Of the viruses concerned, the existence of tobacco rattle virus (TRV) has been reported in Finnish nurseries (TAPIO 1972), but there is no documentation on pea early browning virus (PEBV). eläintutkimuslaitoksen toimintakertomus vuodelta 1963, 1964. [Available at Agric. Res. Centre, Dept. Pest Inv., Jokioinen, Finland.]

- 1976-80. Maatalouden tutkimuskeskus. Kasvintar- 
kastusjaosto. Vuosikertomus 1976-80. [Available at Pl. Quarantine Office, Helsinki, Finland.]

BOAG, B. 1980. Effects of temperature on rate of feeding of the plant parasitic nematodes Rotylenchus robustus, Xiphinema diversicaudatum and Hemicycliophora conida. J. Nematology 12: 193-195.

- 1982. Observations on the population dynamics, life cycle and ecology of plant parasitic nematode Rotylenchus robustus. Ann. Appl. Biol. 100: 157-165.

BINGEFORS, S. 1967. International dispersal of nematodes. Neth. J. Pl. Path. 73, Suppl. 1: 44-60.

BrAACH, H. 1978. Nematologische Probleme beim internationalen Handel mit Obstgehölzen. Nachr.bl. Pfl.schutz DDR 32: 230-234.

BrZESKı, M.W. 1976. Paratylenchus bukowinensis. C.I.H. Descriptions of Plant-parasitic Nematodes. Set 6, No. 79. 2p.

CAIrns, E.J. 1953. A culture-reared, plant parasitic nematode suitable for teaching and research. Phytopath. 43: 105.

Caveness, F.E. \& Jensen, H.J. 1955. Modification of the centrifugal-flotation technique for the isolation and concentration of nematodes and their eggs from soil and plant tissue. Proc. Helminthological Soc. Wash. 22: $87-89$.

Cotten, J. \& Roberts, H. 1981. Root-lesion nematodes (Pratylenchus spp.) in raspberry-cane beds entered for certification in England. Pl. Path. 30: 101-104.

Daulton, R.A. \& Nusbaum, C.J. 1961. The effect of soil temperature on the survival of the root-knot nematodes Meloidogyne javanica and $M$. hapla. Nematologica 6: 280-294.

ESSER, R.P. 1978. How nematodes in plant tissue enter and disperse in Florida nurseries, Fla. Dept. Agric. \& Consumer Services Div. Pl. Ind. Nematology Circ. 43. 2 p.

Faulknér, L.R. \& Darling, H.M. 1961. Pathological histology, hosts, and culture of the potato rot nematode. Phytopath. 51: 778-786.

FERrIS, J.M. 1970. Soil temperature effects on onion seedling injury by Pratylenchus penetrans. J. Nematology 2: 248-251.

HoOPER, D.J. 1970 a. Extraction of nematodes from plant material. In SouTHEY, J.F. (Ed.) Laboratory methods for work with plant and soil nematodes. Min. Agric. Fish. Food Techn. Bull. 2. p. 34-38.

- 1970 b. Handling, fixing, staining and mounting nematodes. In SouTHEY, J.F. (Ed.) Laboratory methods for work with plant and soil nematodes. Min. Agric. Fish. Food Techn. Bull. 2. p. 39-54.

Johnson, P.W. \& Potter, J.W. 1980. Winter survival of root-knot nematodes (Meloidogyne incognita and $M$. hapla) under selected host crops in southern Ontario. Can. J. Pl. Sci. 60: 203-207.

KimpInsKı, J. \& WiLlis, C.B. 1981. Influence of soil temperature and $\mathrm{pH}$ on Pratylenchus penetrans and $P$. crenatus in alfalfa and timothy. J. Nematology 13: 333-337.

Kozlowska, J. \& Wasilewska, L. 1972. Nicienie - pasozyty szkolek drzew owocowych w polsce srodkowej i polnocnej. Acta Agr. Silvestria XII, 1: 17-35.

MALEK, R.B. 1980. Population response to temperature in the subfamily Tylenchorhynchinae. J. Nematology 12: $1-6$.

Mcglohon, N.E., SAsser, J.N. \& Sherwood, R.T. 1962. Effect of fallowing, desiccation, and soil temperature on certain plant-parasitic nematodes. Phytopath. 52: 20-21.

Nolte, H.-W. \& Dieter, A. 1957. Nematoden an Baumschulgewăchsen in Mitteldeutschland. Nematologica 2: 63-67.

OrR, C.C. \& Newton, O.H. 1971. Distribution of nematodes by wind. PI. Dis. Rep. 55: 61-63.

Perry, R.N. 1977. Desiccation survival of larval and adult stages of the plant parasitic nematodes Ditylenchus dipsaci and D. myceliophagus. Parasit. 74: 139-148.

Persson, S. 1968. Nematoder av släktet Trichodorus i sydsvenska åkerjordar och deras förmaga att överföra rattevirus. Stat. Växtskyddsanst. Medd. 14, 123: 167-199.

Pitcher, R.S. \& Mcnamara, D.G. 1970. The effect of nutrition and season of year on the reproduction of Trichodorus viruliferus. Nematologica 16: 99-106.

RoIvAinen, O. 1961. Juurikasankeroinen Heterodera schachtii ja sen elinmahdollisuudet Suomessa. Mimeogr. 39 p. [Available at Univ. Helsinki, Dept. Zool., Helsinki, Finland.]

-, Tinnilä, A. \& Kanervo, V. 1962. Observations on the stem nematode Ditylenchus dipsaci (Kuhn) Filipjev as a pest of red clover in Finland. Ann. Agric. Fenn. 1: 127-132.

Saly, A. 1979. Volne zijuce nematody v lesnej skolke. Lesnicky casopis 25, 2: 141-147.

SARAKOSKı, M.-L. 1978. Förekomst av rotsårnematoden (Pratylenchus) i Finland. Nord. Jordbr.forskn. 60: 147-148.

SASSER, J.N. 1977. Worldwide dissemination and importance of the root-knot nematodes, Meloidogyne spp. J. Nematology 9: 26-29.

SAYre, R.M. 1964. Cold-hardiness of nematodes. I. Effects of rapid freezing on th eggs and larvae of Meloidogyne incognita and M. hapla. Nematologica 10: 168-179.

Seinhorst, J.W. \& Kuniyasu, K. 1969. Rotylenchus uniformis (Thorne) on carrots. Neth. J. Pl. Path. 75: 205-223.

Simons, W.R. 1973. Nematode survival in relation to soil moisture. Meded. Landb.hogesch. Wageningen 73-3. $85 \mathrm{p}$.

Sonderhousen, E., Christensen, R. \& Rasmussen, S. 1968. Förekomst af fritlevende nematoder i danske planteskoler, blomsterlog- og gronsagsarealer, samt un- 
dersogelse af nogle kemiske jordbehandlinsmidlers indflydelse på jordens nematodbestand. Tidsskr. Pl.avl. 72, $2: 245-270$.

TAPIO, E. 1972. The appearance of soil-borne viruses in Finnish plant nurseries. Ann. Agric. Fenn. 44: 83-92. VRain, T.C., Barker, K`R. \& Holtzman, G.I. 1978. Influénce of low temperature on rate of development of Meloidogyne incognita and $M$. hapla larvae. J Nematology 10: 166-171.

\section{SELOSTUS}

\section{Kasveille haitallisten ankeroisten esiintyminen maahantuodussa taimimateriaalissa vuonna 1980}

\section{Sirpa Kurppa}

\author{
Maatalouden tutkimuskeskus, tuhoeläinosasto, \\ 31600 Jokioinen
}

Tutkimuksen tarkoituksena oli selvittäă haitallisen ankeroissaastuntojen leviämistä tuotaessa maahamme taimituotteita. Kasvieriä tutkittiin kaikkiaan 670 ottamalla jokaisesta yksi năyte. Kasvierăt olivat peräisin 42 tuontierăstă. Haitallisia ankeroislajeja tavattiin 201 kasvierässä. Karanteenimäărăysten alaisia lajeja löydettiin 100 kasvierästă. Nämả saastunnat keskittyivăt 26 tuontieräăn, joista 15 erästă löytyi 3 tai useampia saastuneita kasvieriä.

Juuriäkämäankeroiset olivat yleisimpiă saastuntojen aiheuttajia. Niită löytyi 40 kasvilajista ja 81 kasvierästä, $12 \%$ tutkituista kasvieristä. Saastunnat olivat varsin yleisiă mm. happomarjapensaissa ja pioneissa. Eniten saastuntoja tuli kuitenkin avomaalle tarkoitetuissa ruusuissa, joiden tuontikin oli runsainta. Äkämäankeroissaastuntoja tuli myös äitienpäivăruusuissa, mutta leikkoruusujen $\mathbf{4 1}$ juurierăssă löydettiin vain yksi saastunut. Eri ăkämăankeroislajien esiintymisyleisyyttä ei määritetty.

Juurihaava-ankeroista, $P$. penetrans, tai sen sukulaislajia $P$. convallariae löytyi 28 kasvierästä, eli $4 \%$ :sta tutkituista eristä. Enimmät saastunnat löytyivăt ruusuista, vadelmista ja happomarjapensaista. Lahoankeroista, $D$. destructor, löytyi vain yhdestä ruusuẹrästä.

Juurten pinnalla elăviä, sukuihin Paratylenchus, Tylenchorhynchus, Helicotylenchus and Rotylenchus kuuluvia lajeja löytyi useita, mutta varsin pieniä määriä. Kahta virusten levittäjänä tunnettua Trichodorus-suvun lajia löytyi vain 4 kasvierästä kaikista kuitenkin niin vähăn, ettei ankeroisten toimintaa virusten siirtäjänä voitu tarkistaa.
WolnY, S. 1980. Nicienie, pasozyty roslin w szkolkach zadrzewieniowych. Zesz. Problemowe Postepow Nauk Roln. 232: 121-132.

Wyss, U. 1970. Zur Toleranz wandernder Wurzelnematoden gegenuber zunehmender Austrocknung des Bodens und hohen osmotischen Drucken. Nematologica 16: $63-73$.

Ms received May 9, 1985
Äkämäankeroisten maahankulkeutumisesta aiheutuva riski todettiin uhkaavaksi. Ainakin pohjoisimman lajin, M. hapla, säilyminen talven yli avomaalla on todennäköistä ja lisăäntyminen mahdollista, sillä toukan kehitys vaatii alle puolet siită lämpötilojen summasta, joka kertyy Etelä-Suomessa useimpina vuosina. Saastuntariski pahenee, jos tuotujen kasvien jatkokasvatus tapahtuu kylmältă suojattuna. Pahoilta ankeroissaastunnoilta on säästytty kasvihuoneviljelyksillă sen ansiosta, ettă leikkoruusun tuontijuuret ovat olleet tavallista taimitarhamateriaalia puhtaampia saastunnoista. Viileisiin oloihin sopeutuneena juurihaava-ankeroinen saattaa lisääntyă haitalliseksi vähäisistäkin saastuntalähteistä. Se voi tulla merkittăvăksi myős levittämällä sienitauteja. Juurten pintaloisina esiintyvien ankeroisten aiheuttamat saastunnat olivat niin heikkoja, ettei niillă voida olettaa olevan suurta merkitystä.

\section{Acknowledgments}

I thank Professor Matti Nuorteva in the Department of Agricultural and Forest Zoology, University of Helsinki for facilities and the officers of the Plant Quarantine Office, especially Jukka Lumme, for technical help. Useful comments were provided by Professor Martti Markkula, Doctor Jorma Rautapaaă, Annikki Lahtinen and Kari Tiilikkala. This study was financially supported by the foundation: August Johannes and Aino Tiuran Maatalouden Tutkimussaaătiỏ. 